\title{
Treasure Hunting An Underwater Cultural Heritage Approach
}

\section{Mohamed Ahmed Khedr}

Alexandria Centre for Maritime Archaeology \& Underwater Cultural Heritage Greek and Roman Archaeology Department Faculty of Arts - Alexandria University

El-Shatby, Alexandria, Egypt, 2018 


$$
V \cdot \Lambda
$$




\section{ABSTRACT}

\section{Treasure Hunting and Underwater Cultural Heritage}

This article is concerned with Treasure-Hunting and the Underwater Cultural Heritage. Treasure salvage and professional archaeology have fundamentally opposing goals, methods and consequences.

For archaeologists, the priority is to understand the site through interpretation and hypotheses based on the discoveries made. Following investigations, sites are physically and legally protected for future generations. For commercial salvors, time is money and valuable artifacts have to be found and sold as quickly as possible to provide sponsors with a return on their investment.

The term 'treasure-hunting' and considering how it differs from the term 'looting.' Factors that affect treasure-hunting (such as SCUBA diving, culture and media) are discussed. In addition, different methods of work for professional archaeologists and treasure hunters are also investigated.

These aims are presented in several sections accompanied by a main diagram. The underwater cultural heritage is a nonrenewable resource, and if it is not protected, it will soon disappear. 


\section{ملخص البحث}

تتناول هذه المقالة البحث عن الكنوز والتراث الثقافي المغمور بالمياه. إن إستهداف إنقاذ الآثار ذات القيمة المادية فقط وعلم الآثار المهني لهما أهداف ومناهج متعارضة بشكل أساسي.

بالنسبة إلى علماء الآثار ، تتمثل الأولوية في فهم الموقع من خلال التفسير و الفرضيات بناءً على الاكتشافات التي تم إجر اؤها. بعد إجر اء التحقيقات، حيث تتمتع المو اقع بالحماية المادية والقانونية للأجيال القادمة. بالنسبة إلى الصفقات التجارية ، فإن الوقت هو المال ، ويجب العثور على القطع الأثرية القيمة وبيعها في أسرع وقت ممكن لتزويد الرعاة بعائد على استثمار اتهم.

يتم أيضًا عرض الفرق بين مصطلح "صيد الكنوز" و النظر في كيفية اختلافه عن مصطلح "النهب". ومناقثة العوامل التي تثؤثر على البحث عن الكنز (مثل الغوص والثقافة وسائل الإعلام). بالإضافة إلى ذلك ، طرق العمل المختلفة لعلماء الآثار المحترفين و الباحثين عن الكنوز.

يتم تقديم هذه الأهداف في عدة أقسام مصحوبة بمخطط رئيسي. حيث أن التراث الثقافي المغمور بالمياه هو مورد غير متجدد ، وإذا لم يكن محميًا، فسوف يختفي قريبً. 


\section{Introduction}

According to the $1^{\text {st }}$ article of UNESCO 2001 Convention on the Protection of Underwater Cultural Heritage (UNESCO 2001), Underwater Cultural Heritage means "all traces of human existence having a cultural, historical or archaeological character which have been partially or totally under water, periodically or continuously, for at least 100 years” (UNESCO Convention 2001: 11).

Cultural heritage lies beneath the sea is part of the universal heritage of humanity and differs in many aspects from archaeological and historical sites on land as the latter are closely related culturally to people who occupied or passed through a certain area or region (Smith \& Couper 2003: 30; Grenier 2006: x). Yet underwater cultural heritage has a historical and archaeological value as it allows discourse and reflection upon the past. It can reveal a new side of human nature and open windows to a past that would be lost if their archaeological remains was unrecorded.

\section{Context of the research:}

Treasure hunting is the search for and recovery of precious metals, jewelry and other objects of monetary value from shipwrecks which can be sold or marketed for profit. This is a direct distinction to what scientific archaeology is, wherein the search is for a greater understanding of past history through the study of those same material cultural remains (Delgado 1997: 424), not only treasure hunting but also looting refers to the theft of historical artifacts from a heritage sites without authorization. Looting and Treasure hunting carry the same meaning except that treasure hunting 
is conducted by specialized enterprises while looting is done individually.

\section{Factors affecting Treasure Hunting:}

\section{Sport Diving:}

Diving has such a long history as ancient peoples engaged in free diving to collect pearls, sponges and seafood and due to lack of technology at the time, only rudimentary methods were used to enhance diving abilities, such as holding on to a heavy rock to sink or being tethered to a rope to haul a diver back to the surface.

Another method is using diving bell which is one of the earliest types of equipment for underwater work and exploration. Aristotle described a diving bell in his Problematum, that it was a chamber with an open bottom and is lowered into water. It was used by sponge divers in

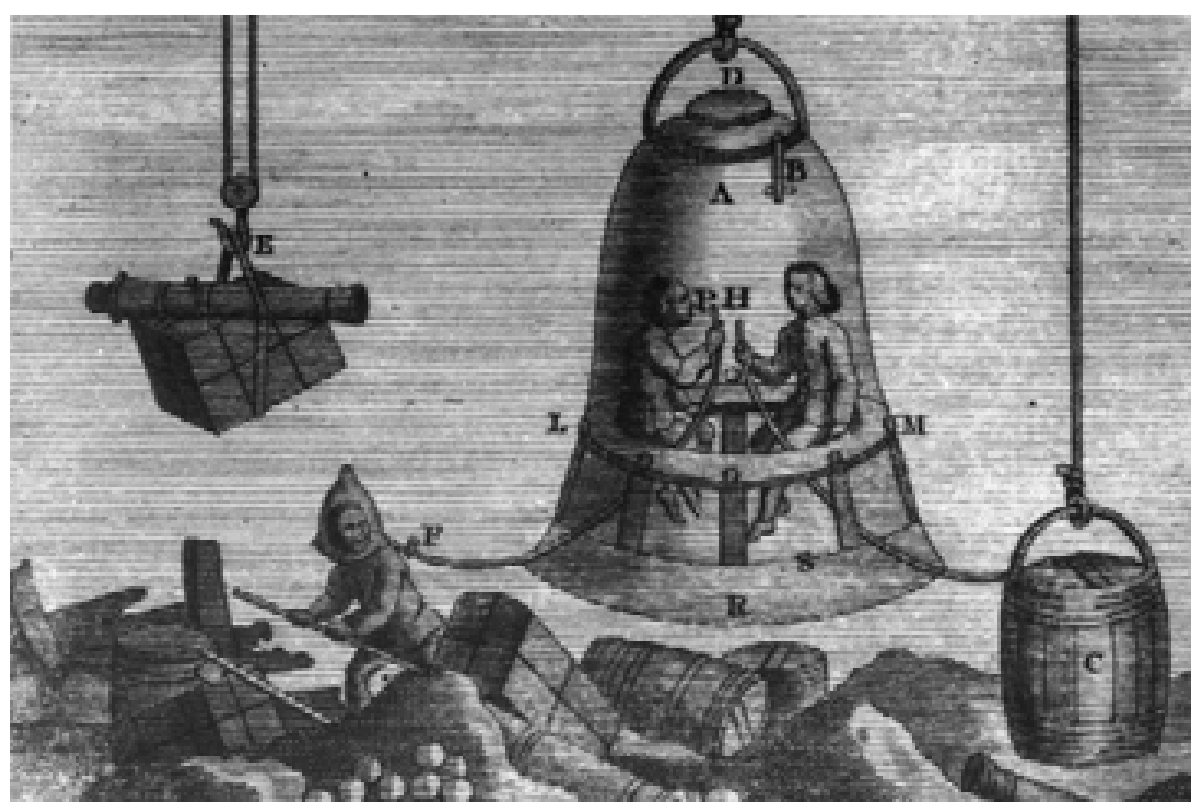

Figure 1: An early depiction of salvage work using a diving bell. Photo credit Hulton ArchiveGetty Images 
the Aegean Sea (Fig. 1).

In 1942 Jacques-Yves Cousteau teamed up with Emile Gagnan and worked on a device that would combine both compressed-air cylinder and regulator which supply air on demand.

By 1943 they had designed and tested a scuba set with a double-hose demand regulator that could be mounted onto air tanks holding up to 200 atmospheres and allowing diving times longer than an hour at significant depths, and they called it the Aqua-Lung (Fig. 2).

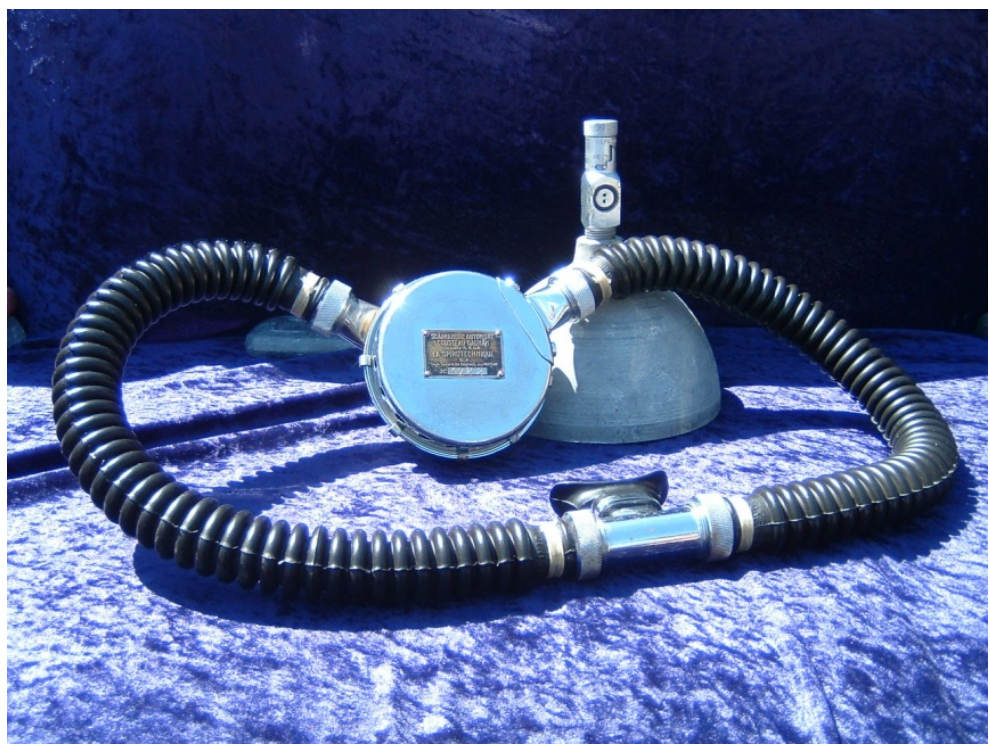

Figure 2: The Aqua-Lung. "The Scuba Museum"

The Aqua-Lung system was only used for military and commercial purposes and un-available to public for sport purpose. Gradually, public perception of scuba diving began to shift to an activity that anyone could try. Moreover, it is 
promoting the idea that they can gain wealth through salvaging from shipwrecks, which puts the submerged heritage at inevitable danger.

SCUBA diving is one of fastest growing sports, there are many certified associations approved the SCUBA diving sport such (PADI, CMAS...etc.). For example, Professional Association for Diving Instructors (PADI) has issued over 25,000,000 diver certification globally since 1967 with average over 900,000 diver certification each year for the last 16 years (Professional Association of Diving Instructors, 2018). Now the problem is not only the amount of certified divers but also PADI issued certification for specialized course "Wreck Diver" which has effects on the looting for underwater cultural heritage and in Mediterranean countries, such activity has become highly fashionable.

There are two distinct types of divers who have an impact on protection: those who truly respect what they see underwater and want to preserve it for future generation, like the Egyptian diver and spear fisherman Kamel Abu El-Saadat, who knew hundreds of submerged archaeological remains in Alexandria and made a number of discoveries and presented his findings to the Greco-Roman Museum.

As for the second type of divers who cared less didn't care at all about what they see and attacked shipwrecks, taking what they can as trophies to prove they have been there and selling it to the collectors (Negueruela 2000: 180; Khalil \& Mustafa 2002: 520; Williams 2004: 131; Stanley 2006: 2; Olsson 2009: 49). 
Consequently, many of underwater archaeological sites are being looted without anyone knowing which means the loss of irreversible parts of cultural heritage as in Sadana Island shipwreck.

Sadana Island Shipwreck is an Ottoman period ship which has been dated to prior to around to the 1760s A.D. and contained large amount of objects such as; fine porcelain, and spices...etc (Fig. 3 and 4), now Sadana Island shipwreck lies on 28-40 m of water at the sandy base of a coral reef 35 $\mathrm{km}$ south Hurghada, a popular Red Sea diving resort. The ship sank and settled on one side, parallel to the reef, with its bow pointed inland. With time, much of the ship broke away and slid down slope into deep sand and was buried yet the stern is particularly well preserved.

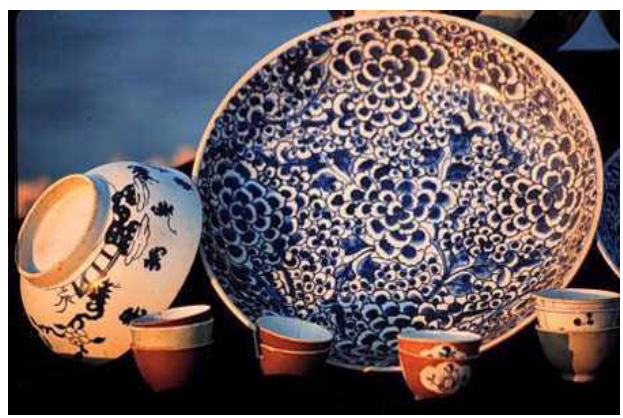

Figure 3: Sadana Island porcelain artifacts. Photo: by N. Piercy

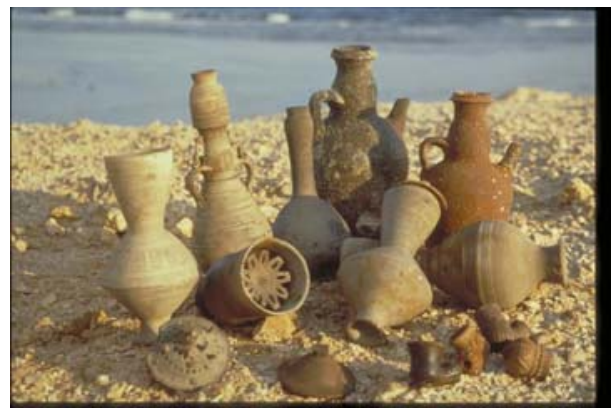

Figure 4: Sadana Island porcelain artifacts. Photo: by N. Piercy 
The discovery in 1996 of about 200 stacked and shattered porcelain artefacts buried in the beach (Fig. 8), suggested that the artefacts were moved (Fig. 9), which; is the individual salvors independently described more than 12,000 porcelain objects removed or broken (Ward 2001:286).

\section{$\underline{\text { Culture and Media }}$}

It is believed that the concepts gained and are firmly grounded during the childhood become the main culture. Therefore, the storyboards for kids such (Sunken Treasure) by Gail Gibbons and (The Secret of the Unicorn, Red Rackham's Treasure) by Herge which presented as an animation movie on 23 December 2011, through those storyboards the researchers use modern technology not only the diving gears, such metal detectors, sonar and sub marine to locate treasure on sea bed, also divers use high-powered machinery to uncover objects buried in sand and to raise them to the surface, build and raise the idea of treasure hunting from the childhood and made it linked only with the gold and precious artifacts.

Commercial media programme $\mathrm{s}$ and movies are promoting the idea of treasure hunting and how they affected the general none-specialists.

Still there are a lot of movies which review the treasure hunters as an archaeologist such (Movie series of Indiana Jones movies, the deep, into the deep ...etc.).

The following section will be dedicated to discuss reviews related to some movies according to imdb.com website. 
(The Deep) released on 17th of June 1977 in United States of America, with estimated budget of 9 million USD for the production. This movie has the tag line (is the treasure worth the terror?!), and has been ranked as an adventure movie. Moreover, the feedbacks toward this movie were only about the story and underwater photography (The Deep (1977)IMDB, 2015).

(Into the blue) released on 30th of September 2005, in United States of America, with estimated budget of 50 million USD for the production. This movie has the tag line (treasure has its price), and has been ranked as an action and adventure movie. Furthermore, the reviews of some users confined between beauty of the scenery, the moderate adventure and scuba diving (Into the Blue (2005)-IMDB, 2015).

Through presenting the story line and some of the feedbacks for the previous movies, it is believed that all the reviews confined to the story lines, photography and the beauty of natural places yet there was no archaeologist reviews for the movies from the academic point of view, which supposed to present the methodology of archaeological survey or excavation and how to collect the data nor how to present it to the public. Despite of through the previous movies as case studies, the stars used the same tools that may be used by the archaeologists but in different methods and technique.

\section{$\underline{\text { Technology }}$}

The technology beginning of diving suit, SCUBA diving system to modern technology such ROV helped the human 
to reach out deeper parts of the seabed which made more shipwrecks and underwater heritage accessible.

The technology available to public use at present time almost all the underwater excavations by treasure hunting specialize firms such as (Odyssey Marine Exploration) are conducted in deep water with most modern technology such as (Side Scan Sonar, ROV, AUV...etc.) (Fig. 5, 6, 7), which sometimes not available for archaeologists, and to use such as modern technology, the treasure hunting companies are funded by investors who seek highest possible profit. (Castro 2010).

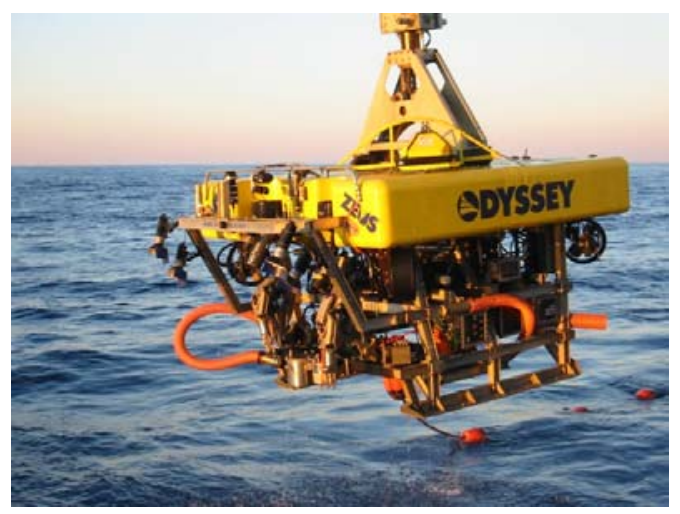

Figure 6: Underwater Metal detector

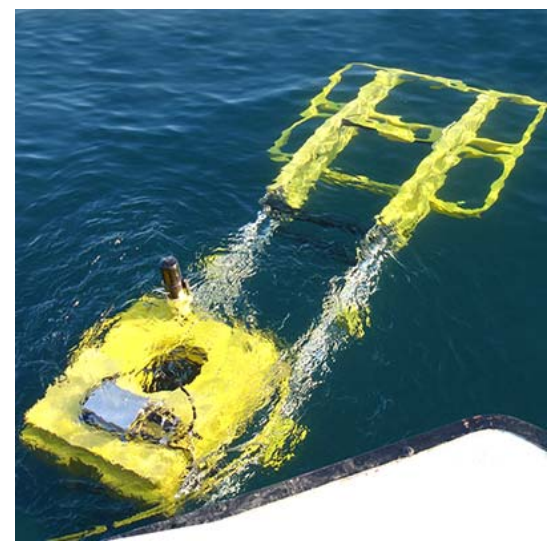




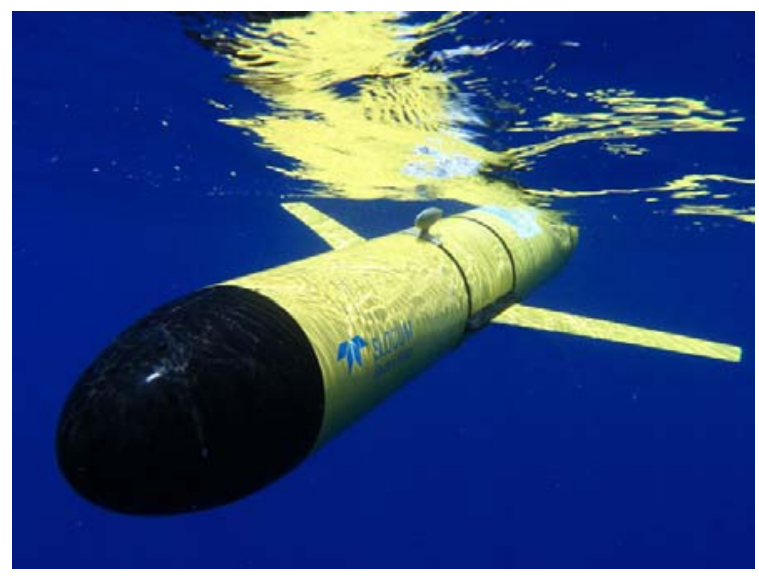

Figure 7: A18D / AUV /

Autonomous Underwater

Vehicle by ECA Group

Therefore, they use the modern technology to search and recover precious objects only for financial profit, and as the cost of technology has fallen recently, more and more treasure hunters have emerged.

\section{Treasure Hunting: International Laws and National Legislations}

Recently many important submerged archaeological sites looted as the wreck of "Tek Sing", which was found in the South China Sea close to Indonesia. Little concern was given by private salvors to the fact that wreck gave testimony to one of the biggest catastrophes in the history of seafaring. Nevertheless, invaluable cargo was dispersed and the wreck destroyed. Other example which shared the same fate was the shipwreck of Nuestra Señora de Atocha, its precious cargo was dispersed in auctions all over the world and there are many other examples as (Titanic Shipwreck, Lena Shoal Shipwreck...etc) so that, a protection of underwater cultural heritage is urgently needed. 


\section{Conclusion}

\section{Treasure Hunting VS Systematic Archaeology}

Archaeologists and treasure hunters does not work together simply because each part has a different methodology of work as archaeologists' excavations aim to the data to reconstruct the past cultures through the study of archaeological remains and the links between those find while treasure hunters aim to profit, so their work depends on searching for valuable finds even they will destroy the site (Fig 8).

Systematic maritime archaeological excavations could be conducted by private organizations such the Institute of Nautical Archaeology (INA) which is entirely private and has over four decades without selling any artifacts. INA is a non-profit research organization founded in 1972 by Dr. George F. Bass. In 1976, INA moved to Texas A\&M University. 
It's believed that the arguments of treasure hunting companies to work with some less developed countries where not necessarily aiming for development, education or environment protection. Therefore, these countries should not allow treasure hunting in their waters; especially they cannot afford high standards of archaeology and their cultural heritage is directly related to these aspects.

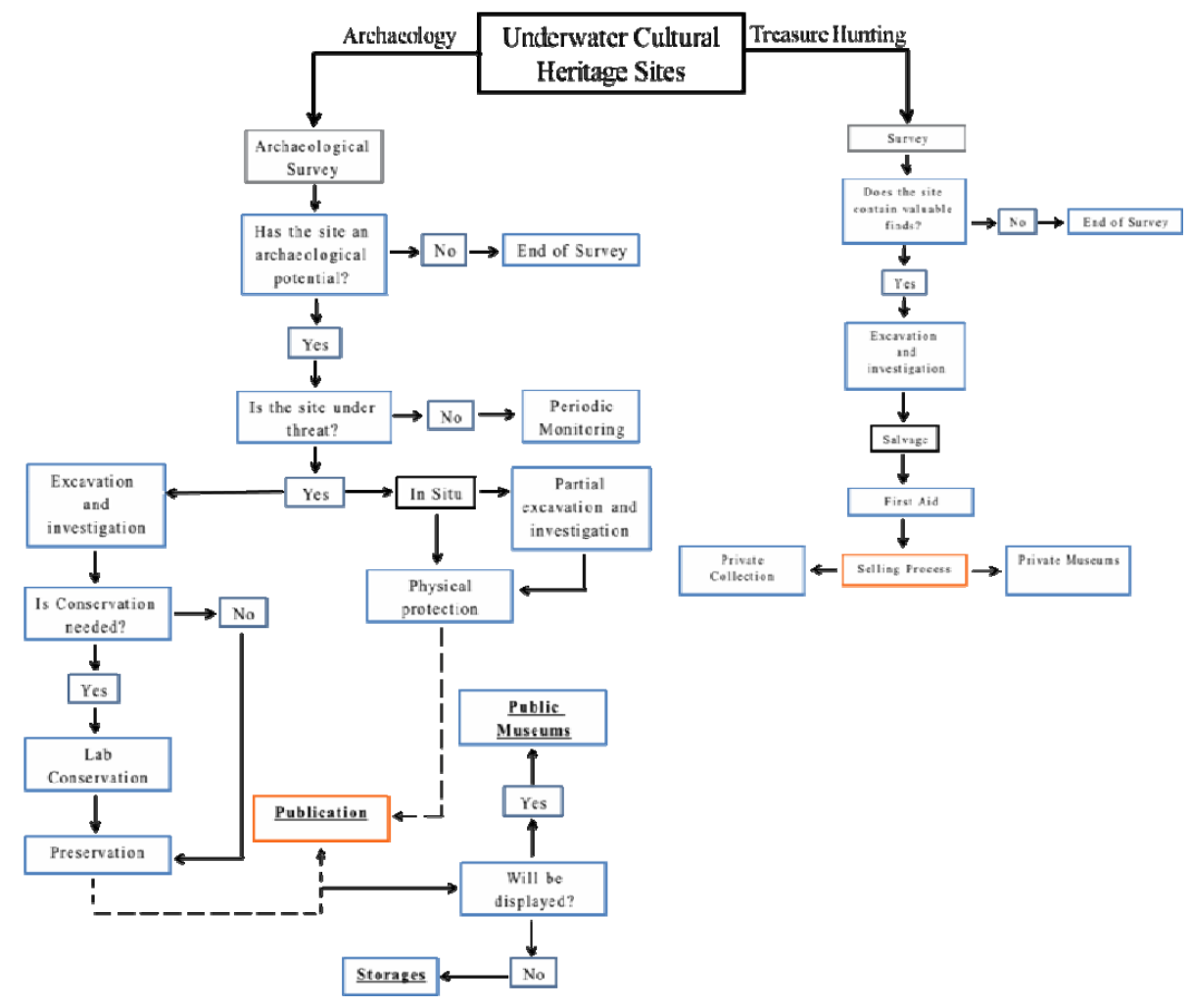

Figure 8: the opposite goals of work between treasure hunting and systematic 


\section{Public awareness}

Although, issuance of international conventions and national legislation to protect $\mathrm{UCH}$, there is no mechanism to abide people or countries to reinforce these conventions. Therefore, the public awareness is the best way to protect the cultural heritage and that could be done through the media, museums and awareness programme $\mathrm{s}$ in schools, also some information and instruction that should be submitted by diving centers.

\section{References:}

Castro, F. (2003, 9 12). Treasure Hunting. Archaeology Volume 56 Number 5.

Grenier, R. 2006, 'Introduction: mankind, and at times nature, are the true risks to underwater cultural heritage,' in Underwater cultural heritage at risk: managing natural and human impacts, eds Grenier, R, Nutley, D \& Cochran I, ICOMOS, Paris.

Khalil, E \& Mostafa, M. 2002, 'Underwater archaeology in Egypt,' in International handbook of underwater archaeology, eds Ruppe, C \& Barstad, J, Plenum Series in Underwater Archaeology, New York.

Negueruela, I. 2000, 'Managing the maritime heritage: the National Maritime Archaeological Museum and National Centre for Underwater Research, Cartagena, Spain,' The International Journal of Nautical Archaeology, vol. 29, no. 2. 
Olsson, A. 2009, 'Some reflections on underwater cultural heritage management,' MACHU Report, no. 2.

Smith, H \& Couper, A. 2003, 'The management of the underwater cultural heritage,' Journal of Cultural Heritage, vol. 4.

Stanley, R. 2006, 'It's all about the 'p's!,' in Underwater cultural heritage at risk: managing natural and human impacts, eds Grenier, R, Nutley, D \& Cochran I, ICOMOS.

United Nations Educational, Scientific and Cultural Organization (UNESCO) 2001, Convention on the Protection of the Underwater Cultural Heritage, United Nations Educational, Scientific and Cultural Organization, Paris.

Williams, K. 2004, Alexandria and the sea - Maritime origins and underwater explorations, Sharp Books International, viewed 9 March 2011.

\section{List of Websites:}

Into the Blue (2005)-IMDB. (2015, August 10). Retrieved from www.imdb.com:

http://www.imdb.com/title/tt0378109/?ref_=nv_sr_1

Professional Association of Diving Instructors. (2018, February 16). Retrieved from www.padi.com www.padi.com/sites/default/files/documents/

The Deep (1977)-IMDB. (2015, July 23). Retrieved from www.imdb.com:

http://www.imdb.com/title/tt0075925/?ref =nv sr 2 
VYE 